\title{
Utilization of antenatal services in slum areas of Aligarh
}

\author{
Arslan Neyaz $^{1 *}$, Priyanka Chintaram Sahu ${ }^{1}$, Malik Shanawaz Ahmed ${ }^{2}$
}

${ }^{1}$ Department of Community Medicine, NIMS Medical College, Jaipur, Rajasthan, India
${ }^{2}$ Department of Community Medicine, Kannur Medical College, Kannur, Kerala, India

Received: 15 March 2015

Revised: 18 March 2015

Accepted: 19 April 2015

\author{
*Correspondence: \\ Dr. Arslan Neyaz, \\ E-mail: arslanneyaz2002@yahoo.com
}

Copyright: (c) the author(s), publisher and licensee Medip Academy. This is an open-access article distributed under the terms of the Creative Commons Attribution Non-Commercial License, which permits unrestricted non-commercial use, distribution, and reproduction in any medium, provided the original work is properly cited.

\begin{abstract}
Background: Today, there are approximately 998 million slum dwellers in the world. As per census 2011, approximately 68 million Indians are living in slums. There have been limited efforts to capture the health of population living in urban slums and most severely affected are the women of childbearing age and children. Objective of this study was to assess the utilization pattern of antenatal care and to identify the factors affecting it among married women of reproductive age at two urban slum areas in Aligarh.

Methods: A cross-sectional survey was carried out from July 2012 to June 2013 in two urban slums of Aligarh with sample of 405 women's selected using systematic random sampling. IBM SPSS Statistics 17 was used for data entry and calculation of statistical tests like proportions, Chi square test.

Results: Antenatal care (ANC) utilization was found to be 74.3\%.89.4\% women received two doses of TT injections and 55.8\% women consumed Iron Folic Acid (IFA) tablets at least for 90 days. Majority (72.4\%) of the women utilized government facility for ANC check-up. Most common reason for not taking ANC was found to be tradition $(34.6 \%)$. Woman's education, husband's education and occupation, birth order and socio-economic status of the family was found to be significantly associated $(\mathrm{p}<0.05)$ with utilization of antenatal care.

Conclusions: Socio-demographic variables of reproductive age group women have impact on utilization of antenatal care services. Social and cultural accessibility is as important as physical accessibility. Important barriers to service utilization in this study include the tradition and economic constraints.
\end{abstract}

Keywords: Antenatal care, Pregnancy, Slum

\section{INTRODUCTION}

Antenatal care refers to pregnancy-related health care, which is usually provided by a doctor, an ANM, or another health professional. ${ }^{1}$ Antenatal care is an important determinant of high maternal mortality rate and one of the basic components of maternal care on which the life of mothers and babies depend. Antenatal checkup is a means to encourage women by the health professionals to deliver in an institution. ${ }^{2}$
Every day, approximately 800 women die from preventable causes related to pregnancy and childbirth. $99 \%$ of all maternal deaths occur in developing countries. ${ }^{3}$ Maternal mortality and morbidity continue to be high despite the existence of national programs for improving maternal and child health in India. In India, although $76 \%$ of women received antenatal care, just over half of mothers $(52 \%)$ had three or more antenatal care visits. ${ }^{1}$ Despite improvements in the coverage of antenatal care for pregnant mothers, only one in four women in Uttar Pradesh received at least three antenatal care visits for their last birth in the past five years. ${ }^{4}$ 
The primary aim of antenatal care is to achieve, at the end of pregnancy, a healthy mother and a healthy baby. ${ }^{5}$ In urban slums accessibility is not a major issue. Traditional practices, lack of awareness of the need for antenatal care, fear of hospitals, attitude and behavior of the staff, and the cost of hospitalization are deterrents to accessing hospital care. ${ }^{6}$

In India, there have been limited efforts to study the health of individuals especially women living in slums. Of the few studies that exist, most have reported considerable differences in the situation of reproductive and child health in between slum and non-slum areas. ${ }^{7}$

\section{Aim \& objectives}

To assess the utilization pattern of antenatal care and to identify the factors affecting it among married women of reproductive age (15-49 years) at two urban slum areas in Aligarh.

\section{METHODS}

It was a community based cross-sectional study conducted from July 2012 to June 2013 at two slums Jeevangarh and Firdaus Nagar, Aligarh where health services were provided by Department of Community Medicine, Jawaharlal Nehru Medical College \& Hospital (JNMCH), AMU, Aligarh. Jeevangarh and Firdaus Nagar are registered slums located in Aligarh city at a distance of $2 \mathrm{Kms}$ from JNMCH, AMU, Aligarh. Jeevangarh has 948 households with a population of 7326 while Firdaus Nagar has 657 households with a population of 3866 .

As prevalence of institutional delivery was $32.6 \%{ }^{8}$ in slums of Aligarh, study was done with sample size of 405 , with $15 \%$ relative error and $10 \%$ non-responders. Probability Proportionate to Size (PPS) sampling was used for deriving appropriate sample from both slums (Figure 1).

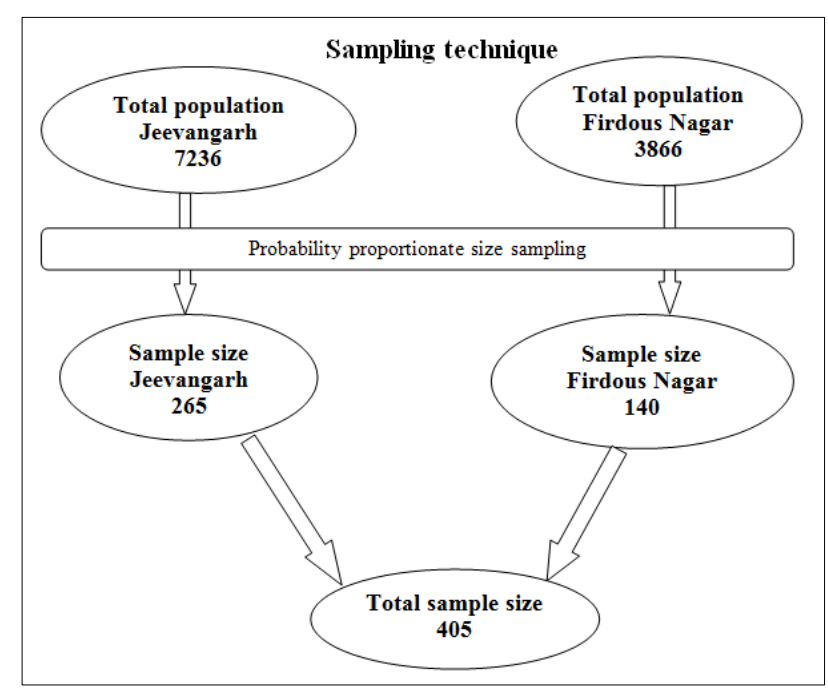

Figure 1: Sampling technique used in the study.
In every slum, the $1^{\text {st }}$ house was selected randomly using the currency note method. Subsequent houses were determined by adding sampling interval to it. Likewise sample size of 405 study subject was chosen using systematic random sampling technique.

Assistance of MSW's (Medico-social worker), BMC's (Block mobilization coordinator) and CMC's (Community mobilization coordinator) was taken to identify the households. Married women of reproductive age (15-49 years) who had a child less than 2 years of age were included. If a woman having a child less than 2 years of age was not found in a house, the next house was taken up. All the subjects were informed about the nature and consequences of the study.

The questionnaire was administered to the head of the household and/or the spouse and/or adult members of the household. After obtaining informed verbal consent, they were interviewed using a semi-structured proforma. Relevant information about the ANC services utilization was recorded along with the socio-demographic data.

Utilization of antenatal care services were compared with socio-demographic characteristics of women by appropriate tests of significance. Cross tabulations were obtained in order to compare women receiving and not receiving antenatal care with respect to the various variables under study and chi-square statistics.

Data analysis was performed using IBM SPSS version 17.0. A ' $p$ ' value of $<0.05$ was considered as significant for rejecting Null Hypothesis.

\section{RESULTS}

\section{Distribution of study population according to socio- demographic factors}

Majority of the women were in the age group 26-30 years $(35.8 \%)$ and husbands were in the age group 26-30 years $(44.7 \%)$. More than half $(56.0 \%)$ of the women and $41.2 \%$ husbands were illiterate. $51.9 \%$ husbands were unskilled worker followed by semi-skilled/skilled worker (24.9\%). Majority of the deliveries were of the birth order $\geq 3$ (39.5\%). Regarding 'Standard of Living Index', $40.7 \%$ families belonged to Medium followed by Low (35.8\%) and High Standard of living (23.5\%) (Table 1).

\section{Antenatal care utilization}

ANC utilization by reproductive age women was $74.3 \%$. Adequate $\mathrm{ANC}(\geq 3 \mathrm{ANC})$ was found to be $51.4 \%$. Majority $(72.4 \%)$ of the women utilized government facility for ANC check-up (Table 2).

Out of 405 women, $89.4 \%$ women received two doses of TT injections and $55.8 \%$ women consumed Iron Folic Acid (IFA) tablets at least for 90 days (Figure 2). 
Table 1: Socio-demographic profile of study population $(n=405)$.

\begin{tabular}{|c|c|c|c|}
\hline \multicolumn{2}{|c|}{ Socio-demographic characteristics } & $\begin{array}{l}\text { Frequency } \\
\text { (n) }\end{array}$ & $\%$ \\
\hline \multirow{4}{*}{$\begin{array}{l}\text { Age of } \\
\text { woman }\end{array}$} & $<21$ years & 51 & 12.6 \\
\hline & 21 to 25 years & 143 & 35.3 \\
\hline & 26 to 30 years & 145 & 35.8 \\
\hline & $>30$ years & 66 & 16.3 \\
\hline \multirow{4}{*}{$\begin{array}{l}\text { Age of } \\
\text { husband }\end{array}$} & $<21$ years & 7 & 1.7 \\
\hline & 21 to 25 years & 76 & 18.8 \\
\hline & 26 to 30 years & 181 & 44.7 \\
\hline & $>30$ years & 141 & 34.8 \\
\hline \multirow{5}{*}{$\begin{array}{l}\text { Education } \\
\text { of woman }\end{array}$} & Illiterate & 227 & 56.0 \\
\hline & Up to primary school & 51 & 12.6 \\
\hline & Up to high school & 85 & 21.0 \\
\hline & Intermediate/diploma & 24 & 5.9 \\
\hline & Graduate and above & 18 & 4.4 \\
\hline \multirow{5}{*}{$\begin{array}{l}\text { Education } \\
\text { of husband }\end{array}$} & Illiterate & 167 & 41.2 \\
\hline & Up to primary school & 60 & 14.8 \\
\hline & Up to high school & 125 & 30.9 \\
\hline & Intermediate/diploma & 23 & 5.7 \\
\hline & Graduate and above & 30 & 7.4 \\
\hline \multirow{2}{*}{$\begin{array}{l}\text { Occupation } \\
\text { of woman }\end{array}$} & Working & 6 & 1.5 \\
\hline & Homemaker & 399 & 98.5 \\
\hline \multirow{5}{*}{$\begin{array}{l}\text { Occupation } \\
\text { of husband }\end{array}$} & Unemployed/retired & 5 & 1.2 \\
\hline & Unskilled & 210 & 51.9 \\
\hline & Semi-skilled/Skilled & 101 & 24.9 \\
\hline & Clerical/Shop/Farm & 82 & 20.2 \\
\hline & Professional & 7 & 1.7 \\
\hline \multirow{2}{*}{ Religion } & Hindu & 7 & 1.7 \\
\hline & Muslim & 398 & 98.3 \\
\hline \multirow{2}{*}{$\begin{array}{l}\text { Type of } \\
\text { family }\end{array}$} & Nuclear & 273 & 67.4 \\
\hline & Joint & 132 & 32.6 \\
\hline \multirow{3}{*}{ Birth order } & 1 & 111 & 27.4 \\
\hline & 2 & 134 & 33.1 \\
\hline & $\geq 3$ & 160 & 39.5 \\
\hline \multirow{3}{*}{$\begin{array}{l}\text { Standard of } \\
\text { living index }\end{array}$} & Low & 145 & 35.8 \\
\hline & Medium & 165 & 40.7 \\
\hline & High & 95 & 23.5 \\
\hline
\end{tabular}

Table 2: Antenatal care utilization among reproductive age women.

\begin{tabular}{|c|c|c|c|c|}
\hline \multicolumn{3}{|c|}{ ANC utilization } & $\begin{array}{l}\text { Frequency } \\
\text { (n) }\end{array}$ & $\%$ \\
\hline \multirow{3}{*}{$\begin{array}{l}\text { Number } \\
\text { of ANC } \\
(n=405)\end{array}$} & \multicolumn{2}{|l|}{ No ANC } & 104 & 25.7 \\
\hline & \multirow{2}{*}{$\begin{array}{l}\mathrm{ANC} \\
\text { received }\end{array}$} & $<3 \mathrm{ANC}$ & 93 & 23.0 \\
\hline & & $\geq 3 \mathrm{ANC}$ & 208 & 51.4 \\
\hline \multirow{2}{*}{$\begin{array}{l}\text { Source } \\
\text { of ANC } \\
(n=301)\end{array}$} & \multicolumn{2}{|c|}{ Govt. facility } & 218 & 72.4 \\
\hline & \multicolumn{2}{|c|}{ Private facility } & 83 & 27.6 \\
\hline
\end{tabular}

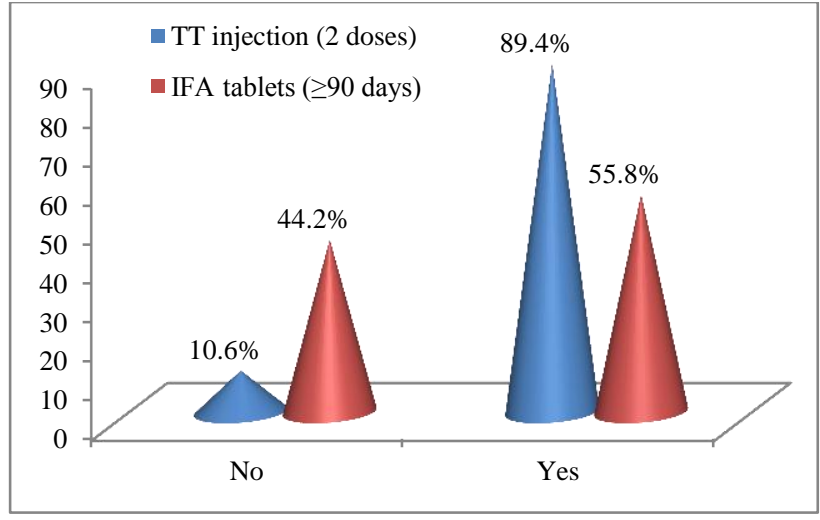

Figure 2: Percentage of TT coverage and IFA tablets consumption.

\section{Reasons for not taking antenatal care}

Most common reason for not taking ANC was found to be tradition $(34.6 \%)$ followed by financial constraints $(20.2 \%)$ and non-availability of accompanying person (20.2\%) (Figure 3).

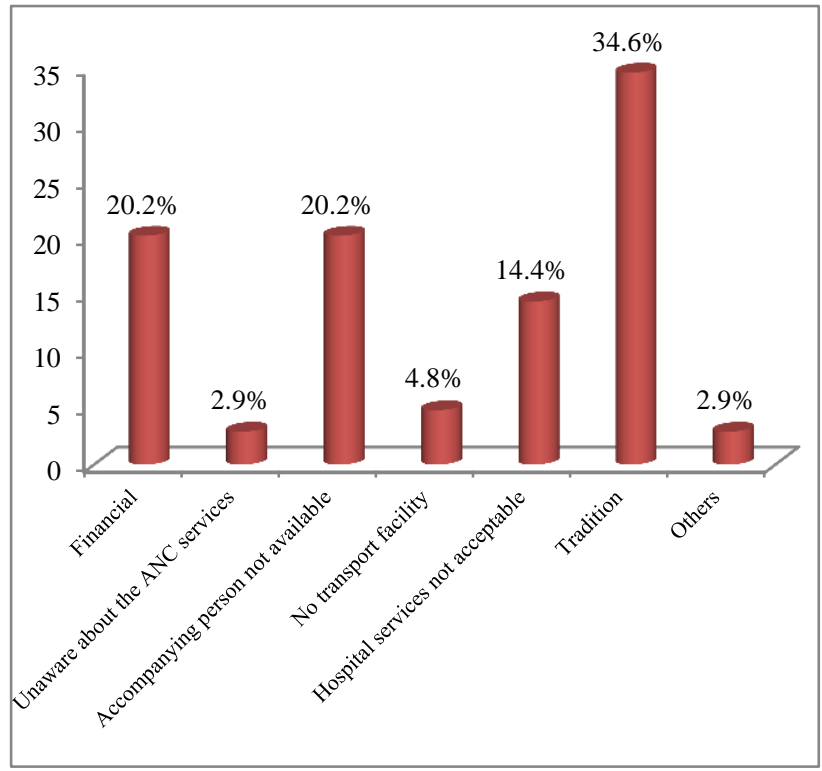

Figure 3: Reason for non-utilization of ANC by reproductive age group women.

\section{Factors affecting antenatal care service utilization}

Women's education, husband's education and occupation, birth order and socio-economic status of the family was found to be significantly associated ( $\mathrm{p}<0.05)$ with antenatal care service utilization while no significant association was observed between antenatal care service utilization and age of woman, woman's occupation and type of family $(\mathrm{p}>0.05)$. Socio-economic status was assessed by using Standard of Living Index (Table 3). 
Table 3: Association of ante-natal care with various socio-demographic factors.

\begin{tabular}{|c|c|c|c|c|c|c|c|}
\hline \multirow{3}{*}{\multicolumn{2}{|c|}{ Socio-demographic factors }} & \multicolumn{4}{|c|}{ ANC } & \multirow{3}{*}{$\chi^{2}$ value } & \multirow{3}{*}{$P$ value } \\
\hline & & \multicolumn{2}{|l|}{ No } & \multicolumn{2}{|l|}{ Yes } & & \\
\hline & & $\mathbf{n}$ & $(\%)$ & $\mathbf{n}$ & $(\%)$ & & \\
\hline \multirow{4}{*}{ Age of women } & $<21$ years & 18 & 35.3 & 33 & 64.7 & \multirow{4}{*}{5.351} & \multirow{4}{*}{0.148} \\
\hline & $21-25$ years & 31 & 21.7 & 112 & 78.3 & & \\
\hline & 26-30 years & 34 & 23.4 & 111 & 76.6 & & \\
\hline & $>30$ years & 21 & 31.8 & 45 & 68.2 & & \\
\hline \multirow{5}{*}{$\begin{array}{l}\text { Women's } \\
\text { education }\end{array}$} & Illiterate & 80 & 35.2 & 147 & 64.8 & \multirow{5}{*}{30.661} & \multirow{5}{*}{$<0.001$} \\
\hline & Upto primary & 13 & 25.5 & 38 & 74.5 & & \\
\hline & Upto high school & 9 & 10.6 & 76 & 89.4 & & \\
\hline & Intermediate/diploma & 1 & 4.2 & 23 & 95.8 & & \\
\hline & Graduate and above & 1 & 5.6 & 17 & 94.4 & & \\
\hline \multirow{5}{*}{$\begin{array}{l}\text { Husband's } \\
\text { education }\end{array}$} & Illiterate & 61 & 36.5 & 106 & 63.5 & \multirow{5}{*}{28.078} & \multirow{5}{*}{$<0.001$} \\
\hline & Upto primary & 20 & 33.3 & 40 & 66.7 & & \\
\hline & Upto high school & 18 & 14.4 & 107 & 85.6 & & \\
\hline & Intermediate/diploma & 3 & 13.0 & 20 & 87.0 & & \\
\hline & Graduate and above & 2 & 6.7 & 28 & 93.3 & & \\
\hline \multirow{2}{*}{$\begin{array}{l}\text { Woman's } \\
\text { occupation }\end{array}$} & Working & 1 & 16.7 & 5 & 83.3 & \multirow{2}{*}{0.259} & \multirow{2}{*}{0.611} \\
\hline & Homemaker & 103 & 25.8 & 296 & 74.2 & & \\
\hline \multirow{5}{*}{$\begin{array}{l}\text { Husband's } \\
\text { occupation }\end{array}$} & Unemployed/retired & 2 & 40.0 & 3 & 60.0 & \multirow{5}{*}{27.426} & \multirow{5}{*}{$<0.001$} \\
\hline & Unskilled worker & 75 & 35.7 & 135 & 64.3 & & \\
\hline & Semi-skilled/skilled worker & 19 & 18.8 & 82 & 81.2 & & \\
\hline & Clerical/shop/farm & 8 & 9.8 & 74 & 90.2 & & \\
\hline & Professional & 0 & 0.0 & 7 & 100.0 & & \\
\hline \multirow{3}{*}{ Birth order } & 1 & 16 & 14.4 & 95 & 85.6 & \multirow{3}{*}{22.514} & \multirow{3}{*}{$<0.001$} \\
\hline & 2 & 27 & 20.1 & 107 & 79.9 & & \\
\hline & $\geq 3$ & 61 & 38.1 & 99 & 61.9 & & \\
\hline \multirow{2}{*}{ Type of family } & Nuclear & 67 & 24.5 & 206 & 75.5 & \multirow{2}{*}{0.567} & \multirow{2}{*}{0.451} \\
\hline & Joint & 37 & 28.0 & 95 & 72.0 & & \\
\hline \multirow{3}{*}{$\begin{array}{l}\text { Socio-economic } \\
\text { status }\end{array}$} & Low & 54 & 37.2 & 91 & 62.8 & \multirow{3}{*}{18.235} & \\
\hline & Medium & 37 & 22.4 & 128 & 77.6 & & $<0.001$ \\
\hline & High & 13 & 13.7 & 82 & 86.3 & & \\
\hline
\end{tabular}

\section{DISCUSSION}

ANC utilization among reproductive age group women was $74.3 \%$ in our study. Similar finding was seen in study conducted at Raipur, Chhattisgarh ${ }^{9}(75.80 \%)$, Aligarh, Uttar Pradesh $(80.4 \%)^{8}$ and Bhopal, Madhya Pradesh $^{10}(63.8 \%)$. While, ANC utilization was lower at Meerut city, Uttar Pradesh ${ }^{11}(49.5 \%)$ and higher at Bijapur, Karnataka ${ }^{12}(87 \%)$. The difference in ANC utilization may be because of variation in health awareness, availability of health infrastructure and health care seeking behavior among women. Majority $(72.4 \%)$ of the women utilized government facility for ANC check-ups. Government facilities were most accepted by women for ANC check-ups in study conducted by Ranganath \& Poornima ${ }^{13}$ (77.7\%), Budimelli \& Chebrolu $^{14}(46.7 \%)$ and Gupta \& Nandeshwar ${ }^{10}(94.9 \%)$.

$89.4 \%$ women received at least two doses of TT injections, similar to this, $87.2 \%$ women at Bhopal, Madhya Pradesh ${ }^{10}$ and $76.2 \%$ women at Meerut, Uttar
Pradesh received two doses of TT. ${ }^{11} 100 \%$ coverage was found in studies of East Godavari, Andhra Pradesh ${ }^{14}$ and in Vadodara, Gujarat. ${ }^{15} 55.8 \%$ women consumed iron folic acid tablets at least for 90 days during their pregnancy. IFA consumption was found to be $5.7 \%$ in Meerut, Uttar Pradesh ${ }^{11}$ and $11.5 \%$ in Indore, Madhya Pradesh $^{16}$ which was much lower than that of our study while higher consumption was seen in study conducted at East Godavari, Andhra Pradesh ${ }^{14}$ (76.7\%) and Vellore, Tamil $\mathrm{Nadu}^{17}(87.2 \%)$.

Most common reason for not utilizing ANC services was tradition $(34.6 \%)$ followed by financial constraints (20.2\%) and non-availability of accompanying person $(20.2 \%)$. Ranganath \& Poornima $^{13}$ reported lack of awareness (49\%), need not felt $(27 \%)$ and financial constraints $(12 \%)$ as common reasons behind lack of early registration. In Pakistan, $75.5 \%$ women did not avail antenatal care because of ignorance about the importance of antenatal care. ${ }^{18}$ 
Women's education, husband's education and occupation, birth order and socio-economic status of the family was found to be significantly associated ( $p<0.05)$ with antenatal care service utilization. Education status of community had impact on awareness regarding health care service utilization. In study conducted by Agrawal et al. ${ }^{19}$ at New Delhi, significant association was reported between antenatal care service utilization and education and occupation of husband while age of women was not significantly associated. Alam et al. ${ }^{18}$ observed significant association of antenatal care service utilization with education of women. No significant difference was found among utilization of antenatal services with teenage pregnancy in Bangalore, Karnataka. ${ }^{13}$

\section{CONCLUSIONS}

Physical accessibility to services does not necessarily lead to service utilization. Social and cultural accessibility is as important as physical accessibility. Important barriers to service utilization in this study include the tradition and economic constraints. Counselling and social mobilization can remove the traditional barriers to a large extent in the health seeking behaviour.

\section{Funding: No funding sources}

Conflict of interest: None declared

Ethical approval: The study was approved by the institutional ethics committee

\section{REFERENCES}

1. IIPS. Maternal health. In: IIPS, eds. National Family Health Survey (NFHS-3) 2005-06. Mumbai, India: International Institute for Population Sciences (IIPS); 2007: 192-196.

2. Bharati S, Pal M, Bharati P. Obstetric care practice in Birbhum district, West Bengal, India. Int J Qual Health Care. 2007;19(4):244-9.

3. World Health Organization (WHO). Maternal mortality. Fact sheet No. 348. Geneva: World Health Organization; 2012. Available at: http://www.who.int/mediacentre/factsheets/fs348/en/ . Accessed 9 January 2015.

4. IIPS. National family health survey (NFHS-3) 200506, Uttar Pradesh. In: IIPS, eds. Uttar Pradesh Survey. Mumbai: International Institute for Population Sciences (IIPS); 2008: 12.

5. Park K. Preventive medicine in obstetrics, paediatrics and geriatrics. In: Park K, eds. Park's Textbook of Preventive and Social Medicine. 23rd ed. Jabalpur: Banarsidas Bhanot; 2015: 523.

6. Fernandez A, Mondkar J, Mathai S. Urban slumspecific issues in neonatal survival. Indian Paediatr. 2003;40:1161-6.
7. Hazarika I. Women's reproductive health in slum populations in India: evidence from NFHS-3. J Urban Health. 2009;87(2):264-77.

8. Khan Z, Mehnaz S, Khalique N, Ansari MA, Siddiqui AR. Poor perinatal care practices in urban slums: possible role of social mobilization networks. Indian J Community Med. 2009;34(2):102-7.

9. Thakur N, Kumar A. A study on delivery and newborn care practices in urban slums of Ganda community. Antrocom Online J Anthropol. 2012;8(1):33-8.

10. Gupta SK, Nandeshwar S. Status of maternal and child health and services utilization patterns in the urban slums of Bhopal, India. Natl J Community Med. 2012;3(2):330-2.

11. Jain T, Singh JV, Bhatnagar M, Garg S, Chopra H, Mohan Y. Status of antenatal care in slums of Meerut city. Indian J Matern Child Health. 2010;12(4):1-7.

12. Angadi MM, Hiremath BR, Sorganvi V. A study on factors influencing selection of place of delivery among pregnant women in urban slums of Bijapur city, Karnataka. Al Ameen J Med Sci. 2013;6(2):189-92.

13. Ranganath TS, Poornima C. A study on utilization of maternal services in urban slums of Bangalore. Int $\mathbf{J}$ Basic Appl Med Sci. 2011;1(1):70-5.

14. Budimelli S, Chebrolu K. Utilisation of maternal health care services in slums of east Godavari district of Andhra Pradesh. Int $\mathbf{J}$ Med Health Sci. 2013;2(2):141-8.

15. Kotecha PV, Patel SV, Shah S, Katara P, Madan G. Health seeking behavior and utilization of health services by pregnant mothers in Vadodara slums. Healthline. 2012;3(1):30-5.

16. Agarwal S, Srivastava K, Sethi V. Maternal and newborn care practices among the urban poor in Indore, India. In: Agarwal S, Srivastava K, Sethi V, eds. Gaps, Reasons and Possible Program Options. New Delhi: Urban Health Resource Center; 2007: 21-26.

17. Mony PK, Verghese L, Bhattacharji S, George A, Thoppuram P, Mathai M. Demography, environmental status and maternal health care in slums of Vellore town, Southern India. Indian J Community Med. 2006;31(4):230-3.

18. Alam AY, Qureshi AA, Adil MM, Ali H. Factors affecting utilization of antenatal care among women in urban slum areas of Islamabad. Rawal Med J. 2004;29:71-5.

19. Agarwal P, Singh MM, Garg S. Maternal health-care utilization among women in an urban slum in Delhi. Indian J Community Med. 2007;32(3):203-5.

DOI: $10.18203 / 2320-1770 . i j r \operatorname{cog} 20150073$

Cite this article as: Neyaz A, Sahu PC, Ahmed MS.

Utilization of antenatal services in slum areas of Aligarh. Int J Reprod Contracept Obstet Gynecol 2015;4:678-82. 